\title{
SOME CONTROLS ON THE RELEASE OF DISSOLVED ORGANIC CARBON BY PLANT TISSUES AND SOILS
}

\author{
T. R. Moore and M. Dalva
}

Soil and plant tissues were used to examine the effect on the release of dissolved organic carbon (DOC) of rinsing over time at two temperatures and under oxic and anoxic conditions in a laboratory incubation. The release of DOC over 60 days of incubation ranged from 0.5 to 189 mg DOC $\mathrm{g}^{-1}$ oven-dry material and was correlated inversely with the degree of decomposition of the material: fresh maple leaves $>$ old maple leaves $>$ Sphagnum moss $>$ fibric peat $>$ hemic peat $=$ sapric peat $>$ Inceptisol A horizon. Rates of DOC release were similar through the duration of the experiment, except for the fresh maple leaves, where release rates fell after 3 day. Rinsing, by the replacement of water in the incubating samples after 20 day, produced slower rates of DOC release, except in the Inceptisol $A$ and sapric peat samples. There was no significant difference between DOC release under oxic and anoxic conditions, except for the Inceptisol A soil, where DOC release was greater under anoxic than under oxic conditions. The rate of DOC release at $22^{\circ} \mathrm{C}$ was an average of 2.4 times greater than at $4{ }^{\circ} \mathrm{C}$, translating into $Q_{10}$ values of about 1.6. At $22^{\circ} \mathrm{C}$ under oxic conditions, DOC production accounted for 14 to $58 \%$ (average $24 \%$ ) of the total $\mathrm{C}$ released as $\mathrm{DOC}+\mathrm{CO}_{2}$, with the highest proportion in the maple leaves. Under anoxic conditions, DOC production accounted for 63 to $95 \%$ (average $82 \%$ ) of the total $\mathrm{C}$ released as DOC $+\mathrm{CO}_{2}+\mathrm{CH}_{4}$. Production of $\mathrm{CH}_{4}$ under anoxic conditions was minor, accounting for $<1 \%$ of the total $\mathrm{C}$ released. Under oxic conditions at $22{ }^{\circ} \mathrm{C}$, the incubations released between 2 and $107 \%$ of the organic $\mathrm{C}$ contained in the samples, the largest proportion of which was released from the plant tissues. Microbial utilization of DOC meant that some $\mathrm{C}$ was double-counted, both as DOC and as subsequently emitted $\mathrm{CO}_{2}$. Under anoxic conditions, 0.0 to $49 \%$ of the sample organic $\mathrm{C}$ was mineralized. The release of DOC represents the balance between production, adsorption, and desorption and microbial utilization. This release differs clearly among samples and among treatment effects. (Soil Science 2001;166:38-47)

Key words: Dissolved organic carbon, organic matter, carbon dioxide, oxic, anoxic, temperature

D ISSOLVED organic carbon (DOC) is a mixture of organic compounds ranging from simple, short-chain to complex humic substances. DOC is important in soils and freshwater systems through its influence on acidity, microbial activity, nutrient availability and mobility, and effect

Department of Geography and Centre for Climate \& Global Change Research, McGill University, 805 Sherbrooke St. W., Montréal, Qué., Canada H3A 2K6. Dr. Moore is corresponding author. E-mail: moore@geos.mcsill.ca

Received April 10, 2000; accepted Sept. 11, 2000. on the toxicity and transport of metals (Thurman, 1985). Concentrations of DOC generally increase from 2 to $3 \mathrm{mg} \mathrm{L}^{-1}$ in precipitation to 10 to $50 \mathrm{mg} \mathrm{L}^{-1}$ in water passing through vegetation canopies, such as forests, and in porewater of organic soils horizons (Dalva and Moore, 1991). In mineral soil profiles, DOC concentrations generally decrease with depth. The DOC concentration in streams ranges from 2 to over $50 \mathrm{mg} \mathrm{L}^{-1}$. The controls on DOC sorption by soil horizons are reasonably well established: laboratory and field experiments have shown that extractable 
iron and aluminum, clay mineralogy and organic carbon are the primary controls on DOC sorption in mineral soils (McDowell and Wood, 1984; Moore et al., 1992; Kaiser et al., 1996; Kaiser and Zech, 1998). Differences in concentration and flux of DOC reflect the relative rates of DOC production, sorption and consumption in systems, as well as the pathways whereby water moves DOC through ecosystems and soils.

Relatively little is known about what determines the ability of plant tissues and soil organic horizons to release DOC. The literature contains many studies that have observed an increase in DOC as water passes through the vegetation or soil organic horizons (Cronan and Aiken, 1985; Moore, 1989; Moore and Jackson, 1989; Marin et al., 1990; Dalva and Moore, 1991; Qualls and Haines, 1991; Koprivnjak and Moore, 1992; Dosskey and Bertsch, 1994). Although there are often strong spatial and temporal variations in the DOC concentration and flux within and between ecosystems, the experimental conditions are too poorly controlled to be able to identify the major factors influencing DOC production.

Christ and David (1996a) determined through laboratory incubations that increases in temperature and moisture content increased the rate of DOC production from the organic horizons of red spruce Spodosols, and they also examined the entrained and adsorbed reservoirs from which the DOC was released (Christ and David, 1996b). Gödde et al. (1996) established that DOC production rates from red spruce forest floors increased with frequency of leaching, rising temperature, and increasing $\mathrm{C}: \mathrm{N}$ ratio; there was, however, no significant relationship between DOC and $\mathrm{CO}_{2}$ production among the eight samples tested. Andersson et al. (2000) showed that temperature and $\mathrm{pH}$ (raised by liming) influenced the leaching of DOC from a forest mor humus in Sweden. Currie and Aber (1997) developed a model of DOC leaching from montane temperate forest floors based on a partitioning of mass loss between DOC and $\mathrm{CO}_{2}$. The proportion lost as DOC was based on litter type (hardwood vs. coniferous) and organic composition, with the proportion of mass loss ascribed to DOC ranging from 0 to 0.74 , resulting in estimated annual fluxes of 22 to $40 \mathrm{~g}$ DOC m$~^{-2}$.

Although they have a common origin in soluble plant materials, the oxidation of soil organic matter, and microbial metabolites (DeLuca and Keeney, 1993; Guggenberger et al., 1994), DOC and $\mathrm{CO}_{2}$ production may be controlled by different processes and organic matter chemistry (Gödde et al., 1996). Thus, the relative importance of $\mathrm{DOC}$ and $\mathrm{CO}_{2}$ as the end-product of decomposition will depend on the type of organic matter and environmental controls.

In this study, we used a laboratory incubation technique to evaluate the effect of type of plant tissue or soil, temperature, rinsing, and oxic or anoxic conditions on the release of DOC. We examined the patterns of release of DOC into solution from three plant tissues and four soil samples at 4 and $22{ }^{\circ} \mathrm{C}$. Rinsing simulated leaching through the replacement of the solution after day 20 and repeating the measurements for two more 20-day cycles. By combining measurements of DOC release and $\mathrm{CO}_{2}$ and $\mathrm{CH}_{4}$ production from the incubating samples, we also determined the effect of these conditions on the fate of the $\mathrm{C}$ mineralized from the samples. We hypothesized that DOC production rates would be greater in fresh than in well decomposed samples, be greater under warm than cold conditions, and be greater under oxic than anoxic conditions.

\section{MATERIALS AND METHODS}

\section{Samples}

Samples of soil and plant tissue were collected from two sites in southern Québec in early summer. At Mont St. Hilaire, $35 \mathrm{~km}$ east of Montreal, samples of fresh and old (over-wintered) sugar maple (Acer saccharum) leaves and the A horizon of a Dystrochrept were collected, as well as the surface layer (0-30-cm depth) of an adjacent swamp peat (Hemist). Maple and other deciduous species such as Betula alleghaniensis and Fagus grandifolia provide the dominant source of organic matter input into these two soils. At a bog peatland (Fibrist) near Mirabel, $50 \mathrm{~km}$ north of Montreal, samples were collected of the moss layer (a mixture of Sphagnum fuscum and Sphagnum magellanicum, the dominant vegetation), as well as a fibric peat sample from a depth of 15 to $30 \mathrm{~cm}$ and a sapric peat sample from a depth of 30 to $60 \mathrm{~cm}$. The samples were stored at $4{ }^{\circ} \mathrm{C}$ until the experiment began. The $\mathrm{pH}$ (in $\mathrm{H}_{2} \mathrm{O}$ ) ranged from 4.5 to 5.4 in the maple leaves and the Inceptisol sample and from 3.9 to 4.8 in the Sphagnum and peat samples. Organic C contents were high (40-45\%) in the plant tissues and peat samples, and the Inceptisol sample contained 4\% org. C. Degree of decomposition ranged from none in the fresh maple leaves and Sphagnum moss to partial in the old maple leaves and fibric 
and hemic peat samples to almost full in the sapric peat and Inceptisol samples.

\section{Methods}

Four-centimeter-thick samples of the seven types of soil and tissue were placed in acidwashed $13 \times 13 \times 8$-m plastic containers. Intact soil samples were used to minimize disturbance. Oven-dry mass of the samples in each container ranged from 2 to $6 \mathrm{~g}$ for the maple leaves, $4 \mathrm{~g}$ for the Sphagnum, 5 to $20 \mathrm{~g}$ for the peat samples, and $100 \mathrm{~g}$ for the Inceptisol. One container contained water as a blank. The samples were saturated with 0.2 to $0.5 \mathrm{~L}$ water, leaving about half of the container free as headspace. Each sample was quickly rinsed 4 to 5 times with water to reduce, as much as possible, the DOC content of the pore water at the start of the incubation. The water from the final rinse was taken as the initial pore water and analyzed for DOC. There were three factors to examine: the effects of rinsing, temperature (4 and $22{ }^{\circ} \mathrm{C}$ ), and oxidation status (oxic and anoxic) on rates of DOC production. Triplicate samples of each soil and tissue type were employed in each treatment.

After 20 days, the samples were drained, rewashed with water, the water replaced and the incubation repeated twice, resulting in measurements of DOC production in parts 1 ( 0 to 20 days), 2 (20 to 40 days), and 3 (40 to 60 days). This allowed a quantification of the amount of DOC lost through sequential leaching.

Samples were incubated at 4 and $22{ }^{\circ} \mathrm{C}$ to evaluate the effect of temperature. To examine the effect of oxic and anoxic conditions, half of the containers were loosely capped to ensure that aerobism was maintained and to reduce evaporation. We did not measure Eh or $\mathrm{pO}_{2}$, but the ratio of $\mathrm{CO}_{2}$ released under the oxic and anoxic treaments (averaging 22:1) suggests that the samples under oxic conditions were at least partially oxic. Furthermore, studies of $\mathrm{O}_{2}$ penetration into saturated peat cores incubated under similar conditions show that at depths of 3 to $4 \mathrm{~cm}, \mathrm{O}_{2}$ concentrations are generally greater than $2 \mathrm{ppm}$ (Blodau, pers. comm.). To create anoxic conditions, the other half of the containers were sealed with the cap, fitted with a SubaSeal septum, and flushed with $\mathrm{N}_{2}$ for 4 to $5 \mathrm{~h}$ to remove $\mathrm{O}_{2}$ from the headspace and most of the porewater.

Water samples were withdrawn on alternate days for the $4{ }^{\circ} \mathrm{C}$ treatment. Sampling was daily for the first week, and then on alternate days, for the $22{ }^{\circ} \mathrm{C}$ treatment, in anticipation of faster changes in DOC and gas exchange. This proce- dure was followed for parts 1 and 2, with samples taken on alternate days in all treatments in part 3. Water samples were taken with a 20-L syringe, filtered through Gelman AE $0.45 \mu \mathrm{m}$ glass fiber paper, and an equivalent volume of distilled water was replaced in the container.

Water samples were analyzed for $\mathrm{pH}$ on a Fisher Accumet pH meter (model 210). DOC concentrations were determined using a Shimadzu TOC-5050 Total Organic Carbon Analyzer, which employs high temperature $\left(680^{\circ} \mathrm{C}\right)$ catalytic combustion. Standards were prepared from potassium biphthalate in concentrations from 0 to $1000 \mathrm{mg} \mathrm{L}^{-1}$. The DOC concentration data were corrected for dilution and evaporation and expressed as DOC $\mathrm{g}^{-1}$ oven-dry soil or plant tissue, determined by oven-drying the samples at the end of the experiment.

Headspace gas samples were obtained at the same time as solution collection for DOC, analysis of carbon dioxide $\left(\mathrm{CO}_{2}\right)$ and methane $\left(\mathrm{CH}_{4}\right)$. In the anoxic treatments, gas samples were withdrawn through the septum of the continuallysealed containers. In the oxic treaments, the containers were capped, an initial sample of headspace gas was taken and another after $2 \mathrm{~h}$. At each sampling date, $0.8 \mathrm{~mL}$ of air was withdrawn for $\mathrm{CH}_{4}$ and $1.0 \mathrm{~mL}$ for $\mathrm{CO}_{2}$ analysis.

Concentrations of $\mathrm{CH}_{4}$ and $\mathrm{CO}_{2}$ were determined on a Shimadzu Mini-2 gas chromatograph with a Flame Ionization Detector and a methanizer, to convert $\mathrm{CO}_{2}$ to $\mathrm{CH}_{4} \cdot \mathrm{N}_{2}$ was used as the carrier gas for the FID at a flow rate of 30 to 40 $\mathrm{mL} \mathrm{min}^{-1}$, with a Porapak Q 80/100 mesh column at $45^{\circ} \mathrm{C}$ and an Injector/Detector temperature of $90{ }^{\circ} \mathrm{C}$. The methanizer used Ni-reduced shimalite to reduce $\mathrm{CO}_{2}$ to $\mathrm{CH}_{4}$ at a detector block temperature of $385^{\circ} \mathrm{C}$ using $\mathrm{He}$ and $\mathrm{H}_{2}$ as the carrier gases. Gas standards of 2.57, 200, and 2000 ppmv $\mathrm{CH}_{4}$, and 353, 2000, and 10000 ppmv $\mathrm{CO}_{2}$ were used.

Total $\mathrm{CO}_{2}$ produced was calculated as the sum of headspace $\mathrm{CO}_{2}$, aqueous $\mathrm{CO}_{2}$ using Henry's Law, and $\mathrm{H}_{2} \mathrm{CO}_{3}$ between $\mathrm{pH} 6$ and 7 , expressed in $\mathrm{mg} \mathrm{CO}_{2} \mathrm{~g}^{-1}$ oven-dry soil or plant tissue. For the samples incubated under oxic conditions, this was based on the changes in headspace $\mathrm{CO}_{2}$ concentration during the container closure, whereas for the anoxically incubated samples, the change in $\mathrm{CO}_{2}$ was cumulative. Production of $\mathrm{CH}_{4}$ under anoxic conditions was based on the cumulative changes in headspace $\mathrm{CH}_{4}$ concentration.

At the end of part 3, the soil and tissue samples were drained, oven-dried at $80{ }^{\circ} \mathrm{C}$, and 
weighed to obtain the dry mass of soil or plant tissue in each of the containers.

\section{RESULTS}

The temporal patterns of the cumulative release of $\mathrm{DOC}$ and $\mathrm{CO}_{2}$ from four representative samples at $22{ }^{\circ} \mathrm{C}$ are presented in Figs. 1 and 2. There was a rapid initial increase over the first 3 days in DOC concentration within porewater of the fresh maple leaves (60 to $80 \mathrm{mg}^{\mathrm{DOC} \mathrm{g}^{-1}}$ $\left.\mathrm{d}^{-1}\right)$, under both oxic and anoxic conditions, after which there was little further increase (Fig. 1). Little DOC $\left(<1 \mathrm{mg}\right.$ DOC g $\left.{ }^{-1} \mathrm{~d}^{-1}\right)$ was released from the fresh maple leaves in the second and third parts after replacing the original water. Rates of $\mathrm{CO}_{2}$ emission remained steady $(6 \mathrm{mg}$ $\mathrm{CO}_{2}-\mathrm{C} \mathrm{g}^{-1} \mathrm{~d}^{-1}$ ) under oxic conditions in the first part, a pattern repeated, at much lower rates (1 to $2 \mathrm{mg} \mathrm{CO}_{2}-\mathrm{C} \mathrm{g}^{-1} \mathrm{~d}^{-1}$ ) during the second and third parts. After initial emission, $\mathrm{CO}_{2}$ production rates remained very small $\left(0.2 \mathrm{mg} \mathrm{CO}_{2-}\right.$ $\mathrm{C} \mathrm{g}^{-1} \mathrm{~d}^{-1}$ ) under anoxic conditions in all three parts of the fresh maple leaves incubation.

In contrast to the fresh maple leaves, the Sphagnum moss tissues released DOC at a slower but more constant rate $\left(0.1 \mathrm{mg}\right.$ DOC $\left.\mathrm{g}^{-1} \mathrm{~d}^{-1}\right)$

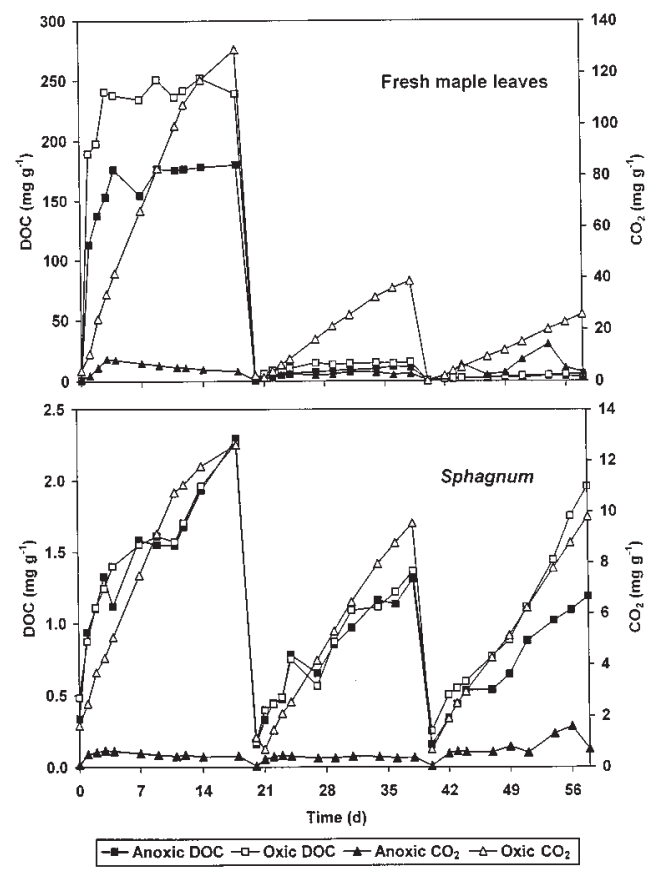

Fig. 1. Patterns of $\mathrm{DOC}$ and $\mathrm{CO}_{2}$ production in samples of fresh maple leaves and Sphagnum incubated under oxic and anoxic conditions at $22{ }^{\circ} \mathrm{C}$. Note variable scale of $y$ axes.

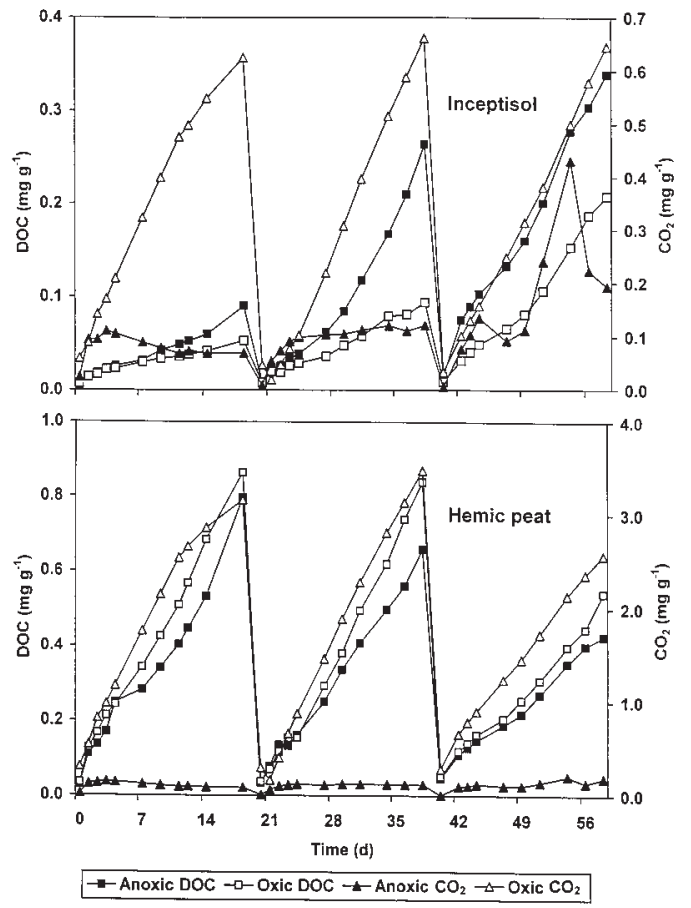

Fig. 2. Patterns of $\mathrm{DOC}$ and $\mathrm{CO}_{2}$ production in samples of Inceptisol A and hemic peat soil samples incubated under oxic and anoxic conditions at $22{ }^{\circ} \mathrm{C}$. Note variable scale of $y$ axes.

under oxic and anoxic conditions, although less DOC was released in the second and third parts of the incubation (Fig. 1). Aerobic $\mathrm{CO}_{2}$ emission rates from the Sphagnum averaged $6 \mathrm{mg} \mathrm{CO}_{2}-\mathrm{C}$ $\mathrm{g}^{-1} \mathrm{~d}^{-1}$ in the first part and declined slightly in the second and third parts. Comparison of the release rates of DOC among the three parts of the experiment showed a significant decrease between parts 1 and 2 and 3 for the fresh maple leaves, suggesting that the reservoir of DOC in this tissue is rapidly depleted in the first part (Table 1). This pattern was less pronounced for the Sphagnum sample, and the old maple leaves followed a pattern intermediate between the fresh maple leaves and the Sphagnum moss. The same temporal relationships of DOC release occurred at $4{ }^{\circ} \mathrm{C}$ but are not reported here.

The temporal pattern of DOC release for the soil samples was different, illustrated in Fig. 2 for the Inceptisol and hemic peat samples. Rates of DOC release from the Inceptisol were small

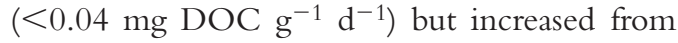
the first to third parts to averages of 0.08 and 0.12 mg DOC g $\mathrm{g}^{-1} \mathrm{~d}^{-1}$ under both oxic and anoxic conditions at $22{ }^{\circ} \mathrm{C}$; this pattern was much less 
TABLE 1

Quotient of the amount of DOC produced in Parts 2 and 3 of the incubation, compared with Part 1

\begin{tabular}{|c|c|c|c|c|c|c|}
\hline \multirow{2}{*}{ Sample } & \multirow[b]{2}{*}{ Part } & \multicolumn{2}{|c|}{$22^{\circ} \mathrm{C}$} & \multicolumn{2}{|c|}{$4^{\circ} \mathrm{C}$} & \multirow{2}{*}{ Mean } \\
\hline & & Oxic & Anoxic & Oxic & Anoxic & \\
\hline \multirow[t]{2}{*}{ Fresh maple leaves } & 2 & 0.09 & 0.09 & 0.13 & 0.13 & $0.11^{* * *}$ \\
\hline & 3 & 0.04 & 0.03 & 0.05 & 0.10 & $0.05^{* * *}$ \\
\hline \multirow[t]{2}{*}{ Old maple leaves } & 2 & 0.28 & 0.26 & 0.46 & 0.45 & $0.38^{*}$ \\
\hline & 3 & 0.18 & 0.21 & 0.54 & 0.57 & $0.38^{* *}$ \\
\hline \multirow[t]{2}{*}{ Inceptisol A } & 2 & 2.06 & 3.17 & 1.00 & 1.08 & 1.83 \\
\hline & 3 & 4.85 & 4.15 & 1.00 & 1.59 & 2.90 \\
\hline \multirow[t]{2}{*}{ Hemic peat } & 2 & 1.02 & 0.73 & 1.01 & 0.96 & 0.93 \\
\hline & 3 & 0.59 & 0.52 & 0.74 & 0.67 & $0.63^{*}$ \\
\hline \multirow[t]{2}{*}{ Sphagum } & 2 & 0.75 & 0.72 & 0.53 & 0.85 & $0.71 *$ \\
\hline & 3 & 1.17 & 0.68 & 0.76 & 0.75 & 0.84 \\
\hline \multirow[t]{2}{*}{ Fibric peat } & 2 & 0.61 & 0.94 & 0.18 & 0.67 & $0.67^{*}$ \\
\hline & 3 & 0.64 & 1.02 & 0.33 & 0.67 & $0.66^{*}$ \\
\hline \multirow[t]{2}{*}{ Sapric peat } & 2 & 1.41 & 0.95 & 0.67 & 0.97 & 1.00 \\
\hline & 3 & 1.14 & 0.76 & 0.40 & 1.21 & 0.88 \\
\hline
\end{tabular}

***, ${ }^{* *}$ and ${ }^{*}$ indicate significant differences from 1.00 at $0.001,0.01$ and 0.05 level, respectively, using paired $t$ test.

pronounced at $4{ }^{\circ} \mathrm{C}$ (Table 1). Aerobic $\mathrm{CO}_{2}$ emission rates from the Inceptisol were slow (0.05 $\mathrm{mg} \mathrm{CO}_{2}-\mathrm{C} \mathrm{g}^{-1} \mathrm{~d}^{-1}$ ) and similar among the three parts (Fig. 2). The hemic peat sample showed

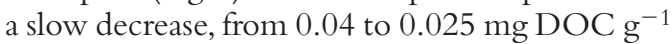
$\mathrm{d}^{-1}$, in DOC release through parts 1 through 3 , and aerobic $\mathrm{CO}_{2}$ emission rates also declined in part 3 (Fig. 2). This pattern of a slow decrease in DOC release through leaching also occurred in the fibric and sapric peat samples (Table 1).

The amount of DOC released during the ex- periment ranged from 0.2 to $260 \mathrm{mg}$ DOC $\mathrm{g}^{-1}$ (Table 2), with an overall ranking among samples of

fresh maple leaves $>$ old maple leaves $>$ Sphagnum moss $>$ fibric peat hemic peat $=$ sapric peat $>$ Inceptisol

This pattern is the same as the degree of decomposition of the samples, from fresh plant tissues to well-humified soil organic matter.

The influence of oxic and anoxic conditions on DOC release from the seven samples is shown by the data in Table 2 and expressed as quotients

TABLE 2

Release of DOC $\left(\mathrm{mg} \mathrm{g}^{-1}\right)$ from samples over 60 days of incubation combining Parts 1, 2, and 3 under oxic and anoxic conditions at 4 and $22^{\circ} \mathrm{C}$

\begin{tabular}{|c|c|c|c|c|c|}
\hline \multirow{3}{*}{ Sample } & \multicolumn{4}{|c|}{ Treatment } & \multirow{3}{*}{ Mean } \\
\hline & \multicolumn{2}{|c|}{$22{ }^{\circ} \mathrm{C}$} & \multicolumn{2}{|c|}{$4{ }^{\circ} \mathrm{C}$} & \\
\hline & Oxic & Anoxic & Oxic & Anoxic & \\
\hline Fresh maple leaves & $\begin{array}{c}260.0 \\
(17.4)\end{array}$ & $\begin{array}{c}195.2 \\
(16.5)\end{array}$ & $\begin{array}{c}153.7 \\
(13.9)\end{array}$ & $\begin{array}{c}148.2 \\
(15.1)\end{array}$ & 189.3 \\
\hline Old maple leaves & $\begin{array}{c}21.1 \\
(4.1)\end{array}$ & $\begin{array}{c}21.4 \\
(3.8)\end{array}$ & $\begin{array}{c}7.7 \\
(1.2)\end{array}$ & $\begin{array}{l}11.7 \\
(3.1)\end{array}$ & 15.5 \\
\hline Inceptisol A & $\begin{array}{c}0.35 \\
(0.09)\end{array}$ & $\begin{array}{c}0.69 \\
(0.03)\end{array}$ & $\begin{array}{c}0.25 \\
(0.07)\end{array}$ & $\begin{array}{c}0.16 \\
(0.10)\end{array}$ & 0.4 \\
\hline Hemic peat & $\begin{array}{c}2.24 \\
(0.16)\end{array}$ & $\begin{array}{c}1.89 \\
(0.23)\end{array}$ & $\begin{array}{c}0.62 \\
(0.03)\end{array}$ & $\begin{array}{c}0.60 \\
(0.08)\end{array}$ & 1.3 \\
\hline Sphagnum & $\begin{array}{c}5.59 \\
(0.28)\end{array}$ & $\begin{array}{c}4.79 \\
(0.46)\end{array}$ & $\begin{array}{c}1.93 \\
(0.48)\end{array}$ & $\begin{array}{c}2.25 \\
(0.42)\end{array}$ & 3.6 \\
\hline Fibric peat & $\begin{array}{c}2.86 \\
(0.25)\end{array}$ & $\begin{array}{c}2.76 \\
(0.22)\end{array}$ & $\begin{array}{c}1.13 \\
(0.26)\end{array}$ & $\begin{array}{c}1.07 \\
(0.06)\end{array}$ & 2.0 \\
\hline Sapric peat & $\begin{array}{c}1.79 \\
(0.19)\end{array}$ & $\begin{array}{c}1.69 \\
(0.18)\end{array}$ & $\begin{array}{c}0.69 \\
(0.07)\end{array}$ & $\begin{array}{c}0.93 \\
(0.18)\end{array}$ & 1.3 \\
\hline
\end{tabular}

Figures in parentheses indicate the standard deviation of the triplicate samples used in each treatment. 
for each sample and temperature treatment in Table 3. At both 22 and $4{ }^{\circ} \mathrm{C}$, there was no overall significant difference between DOC release rates under oxic and anoxic conditions. Some treatments did show significant differences, such as fresh maple leaves at $22{ }^{\circ} \mathrm{C}$ (oxic $>$ anoxic) and the Inceptisol at $22{ }^{\circ} \mathrm{C}$ (oxic $<$ anoxic) and at 4 ${ }^{\circ} \mathrm{C}$ (oxic $>$ anoxic).

The influence of temperature on DOC release can be assessed from the quotients of 22:4 ${ }^{\circ} \mathrm{C}$ rates in Table 3 . This quotient was small $(0.8$ to 1.1) for the fresh maple leaves, but it averaged 2.6 for both the oxic and anoxic treatments of the other samples. These quotients translate into an overall $\mathrm{Q}_{10}$ value (between 4 and $22^{\circ} \mathrm{C}$ ) of 1.6, excluding the fresh maple leaves.

A summary of the three factor effects (rinsing, oxic or anoxic conditions, and temperature) on DOC release from all samples is shown in Fig. 3 and has been subjected to an Analysis of Variance (Table 4). For each factor effect, expressed as the DOC production quotient, there are large variations, indicating the complexity of the processes leading to DOC release from this wide range in organic matter and experimental conditions (Fig. 3). The overall pattern (Table 4), however, is a decrease in DOC production through rinsing $(P<0.01$ in all samples but the sapric peat), little effect of oxic/anoxic conditions $(P<$ 0.01 in Inceptisol A and hemic peat samples), and an increase in response to temperatures raised from 4 to $22{ }^{\circ} \mathrm{C}(P<0.01$ in all but the fresh maple leaves). The difference among the seven samples was significant at $P<0.01$.

Separation of the $\mathrm{C}$ mobilization into DOC, $\mathrm{CO}_{2}$, and $\mathrm{CH}_{4}$ for the seven samples at $22{ }^{\circ} \mathrm{C}$ is shown in Table 5 . Under oxic conditions, the amount of DOC released from the samples ranged from 0.4 to $260 \mathrm{mg} \mathrm{g}^{-1}$, and the $\mathrm{CO}_{2}$ emitted ranged from 2 to $192 \mathrm{mg} \mathrm{CO}_{2}-\mathrm{C} \mathrm{g}^{-1}$. The division between these forms varied greatly among the samples. Although 1.4 times more DOC than $\mathrm{CO}_{2}-\mathrm{C}$ was released from the fresh maple leaves, there was between 4.1 and 6.3 times as much $\mathrm{CO}_{2}-\mathrm{C}$ as DOC released from the five soil samples. The old maple leaves released about 2.5 times as much $\mathrm{CO}_{2}-\mathrm{C}$ as DOC. When the DOC and $\mathrm{CO}_{2}-\mathrm{C}$ release rates are combined, the percentage of the sample $\mathrm{C}$ released over the 60-day incubation period ranged from $2 \%$ for the humic peat to $107 \%$ for the fresh maple leaves. This latter figure suggests there is some "double-counting" of C among DOC and $\mathrm{CO}_{2}$. Where the DOC is labile, such as in the fresh maple leaves, its release from the organic matter will initially be recorded as DOC, but over the 20- day incubation period, much of this DOC may be utilized by microbes and converted to $\mathrm{CO}_{2}$, and thus be measured twice. As the samples were incubated in the dark, there is little chance that atmospheric $\mathrm{CO}_{2}$ could be incorporated in the sample or solution.

Under anoxic conditions, DOC release ranged from 0.7 to $195 \mathrm{mg} \mathrm{g}^{-1}$, whereas the $\mathrm{CO}_{2}$ produced ranged from only 0.1 to $12.8 \mathrm{mg} \mathrm{CO}_{2}-\mathrm{C}$ $\mathrm{g}^{-1}$ (Table 4). Production of $\mathrm{CH}_{4}$ was an insignificant part of the $\mathrm{C}$ budget, apart from the old maple leaves, which, lying on the forest floor, may have had an active methanogenic population. In all samples incubated anaerobically, DOC release rates were larger than $\mathrm{CO}_{2}-\mathrm{C}$ production rates by factors ranging from 2 (in the old maple leaves) through 3 to 8 in the peat and Sphagnum samples, to 19 in the fresh maple leaves. Although some $\mathrm{CO}_{2}$ was produced intially in the anaerobic incubations, little further production occurred after 4 or 5 days. The amount of $\mathrm{C}$ released as DOC, $\mathrm{CO}_{2}$, and $\mathrm{CH}_{4}$ during the incubation ranged from 1 to $49 \%$ of the original sample C, an average of $25 \%$ of that released in the aerobic incubations. Some indication of the influence of anoxic conditions on $\mathrm{CO}_{2}$ production is revealed by oxic:anoxic $\mathrm{CO}_{2}$ production quotients

TABLE 3

Quotient of DOC release under oxic and anoxic conditions at $4{ }^{\circ} \mathrm{C}$ and $22{ }^{\circ} \mathrm{C}$ over 60 days

\begin{tabular}{lcccc}
\hline & \multicolumn{3}{c}{ Treatment } \\
\cline { 2 - 5 } Sample & $\begin{array}{c}22{ }^{\circ} \mathrm{C} \\
\text { oxic:anoxic }\end{array}$ & $\begin{array}{c}{ }^{\circ} \mathrm{C} \\
\text { oxic:anoxic }\end{array}$ & $\begin{array}{c}\text { Oxic } \\
22: 4\end{array}$ & $\begin{array}{c}\text { Anoxic } \\
22: 4\end{array}$ \\
\hline Fresh maple leaves & 1.33 & 1.04 & 1.69 & 1.32 \\
Old maple leaves & 0.99 & 0.66 & 2.75 & 1.83 \\
Inceptisol A & 0.51 & 1.55 & 3.61 & 4.31 \\
Hemic peat & 1.19 & 1.03 & 2.89 & 2.12 \\
Sphagnum & 1.17 & 0.86 & 2.53 & 2.53 \\
Fibric peat & 1.04 & 1.06 & 2.59 & 1.82 \\
Sapric peat & 1.06 & 0.74 & & \\
\hline
\end{tabular}




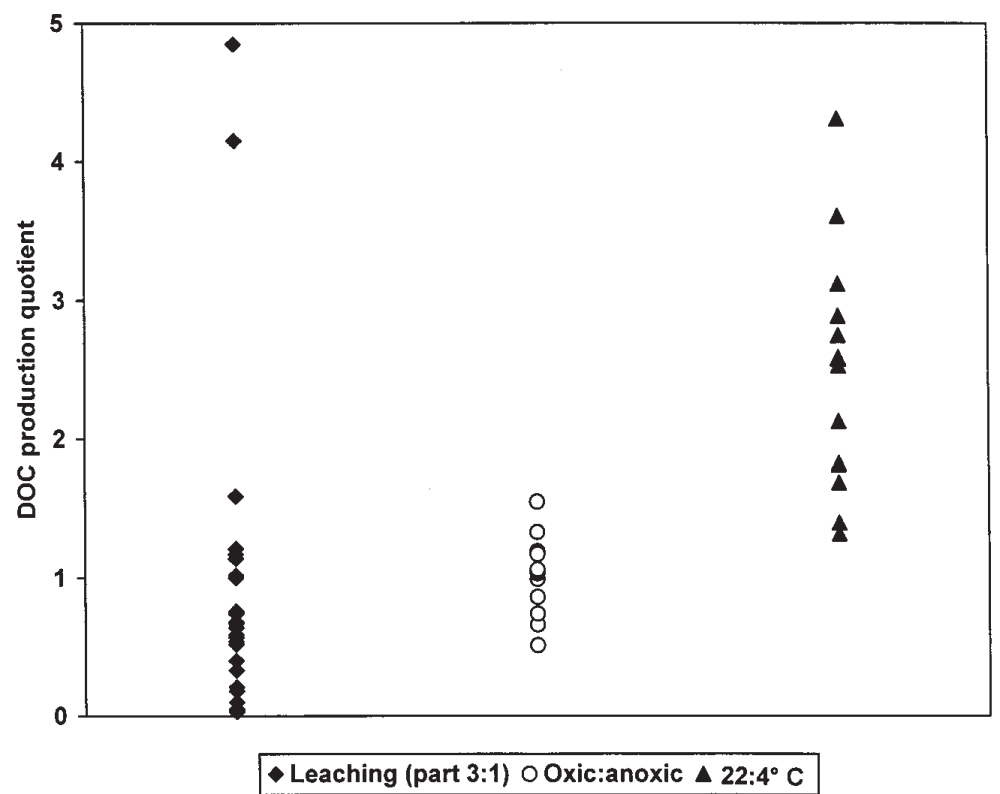

Fig. 3. Graphical summary of the importance of leaching, oxic/anoxic conditions and temperature on DOC release. Each point represents one sample, expressed as the ratio between parts 3 and 1, oxic and anoxic, and 22 and $4{ }^{\circ} \mathrm{C}$ treatments.

at $22{ }^{\circ} \mathrm{C}$ ranging from 4 in the old maple leaves to 16 to 35 for the other samples.

\section{DISCUSSION}

The DOC release rates presented here are net rates and represent the balance between the release of DOC from organic matter, its exchange and sorption on particle surfaces, its incorporation into microbial tissue, and its release as $\mathrm{CO}_{2}$ and $\mathrm{CH}_{4}$ through decomposition. Assessments of the bioavailability of DOC in soils are few (e.g., Boyer and Groffman, 1996; Qualls and Haines,
1992; Yano et al., 1998) though the lability of DOC in freshwater bodies such as streams and lakes has been studied more intensively (e.g. Leff and Meyer, 1991; Søndergaard and Middelboe, 1995). Qualls and Haines (1992) reported that between 14 and $33 \%$ of the DOC released in a deciduous forest was metabolized over 134 days, with most metabolism occurring in the first 20 days. Relative DOC biodegradability decreased from throughfall and forest floor to B and A horizons; a deciduous leaf leachate sample showed the highest biodegradation rate, $45 \%$ in 20 days

TABLE 4

Results of Analysis of Variance summarizing differences in rates of DOC production within and among samples under varying factors of rinsing, oxic-anoxic conditions and temperature. Differences among sample types as identified under the combined category. For each sample, $\mathrm{n}=36$

\begin{tabular}{|c|c|c|c|c|c|c|c|c|}
\hline \multirow{3}{*}{ Sample } & \multicolumn{8}{|c|}{ Factor } \\
\hline & \multicolumn{2}{|c|}{ Rinsing } & \multicolumn{2}{|c|}{ Oxic-anoxic } & \multicolumn{2}{|c|}{ Temperature } & \multicolumn{2}{|c|}{ Type } \\
\hline & F-ratio & $P$ & F-ratio & $P$ & F-ratio & $P$ & F-ratio & $P$ \\
\hline Fresh maple leaves & 540.6 & $<0.001$ & 0.5 & 0.501 & 2.7 & 0.115 & & \\
\hline Old maple leaves & 50.5 & $<0.001$ & 0.3 & 0.572 & 63.1 & $<0.001$ & & \\
\hline Inceptisol A & 28.2 & $<0.001$ & 12.8 & $<0.001$ & 101.0 & $<0.001$ & & \\
\hline Hemic peat & 16.3 & $<0.001$ & 8.3 & 0.008 & 293.5 & $<0.001$ & & \\
\hline Sphagnum & 6.1 & 0.007 & 2.3 & 0.131 & 238.9 & $<0.001$ & & \\
\hline Fibric peat & 18.9 & $<0.001$ & 1.5 & 0.239 & 434.7 & $<0.001$ & & \\
\hline Sapric peat & 1.4 & 0.257 & 1.6 & 0.224 & 196.0 & $<0.001$ & & \\
\hline Combined & 587.9 & $<0.001$ & 0.4 & 0.539 & 15.3 & $<0.001$ & 791.8 & $<0.001$ \\
\hline
\end{tabular}


TABLE 5

Release of DOC, $\mathrm{CO}_{2}$, and $\mathrm{CH}_{4}$ from soils and plant tissues incubated over 60 days at $22{ }^{\circ} \mathrm{C}$ under oxic and anoxic conditions. Units are $\mathrm{mg} \mathrm{C} \mathrm{g}{ }^{-1}$, except for $\mathrm{CH}_{4}$ which is $\mu \mathrm{g} \mathrm{CH}_{4}^{-} \mathrm{C} \mathrm{g}^{-1}$.

Figures in brackets represent the combined (DOC $\left.+\mathrm{CO}_{2}+\mathrm{CH}_{4}\right)$ percentage of the sample $\mathrm{C}$ released during the incubation

\begin{tabular}{lrrrrrrrr}
\hline \multirow{2}{*}{ Sample } & \multicolumn{4}{c}{ Oxic } & & \multicolumn{4}{c}{ Anoxic } \\
\cline { 2 - 4 } \cline { 7 - 9 } & DOC & $\mathrm{CO}_{2}$ & $\mathrm{C}$ released (\%) & & DOC & $\mathrm{CO}_{2}$ & $\mathrm{CH}_{4}$ & C released (\%) \\
\hline Fresh maple leaves & 260.0 & 192.1 & 107 & & 195.2 & 10.1 & $<0.1$ & 49 \\
Old maple leaves & 21.1 & 53.4 & 19 & & 21.4 & 12.8 & 70 & 9 \\
Inceptisol A & 0.4 & 1.7 & 4 & & 0.7 & 0.1 & 0.5 & 6 \\
Hemic peat & 2.2 & 9.4 & 3 & & 1.9 & 0.4 & 0.9 & 2 \\
Sphagnum & 5.6 & 33.5 & 9 & & 4.8 & 1.5 & $<0.1$ & 1 \\
Fibric peat & 2.9 & 18.0 & 5 & & 2.8 & 0.6 & $<0.1$ & 0.1 \\
Sapric peat & 1.8 & 7.3 & 2 & & 1.7 & 0.2 & $<0.1$ & 0.1 \\
\hline
\end{tabular}

(Qualls and Haines, 1992). Boyer and Groffman (1996) reported that 10 to $25 \%$ of waterextractable soil $\mathrm{C}$ was biodegradable over 14 days. Of the DOC contained in rivers and lakes, 15 to $20 \%$ may be regarded as labile, or subject to microbial utilization at 15 to $20{ }^{\circ} \mathrm{C}$ under oxic conditions and for a period of about 1 week (Søndergaard and Middelboe, 1995). One can speculate that a larger proportion of the DOC released by plant tissues is labile compared with DOC released from soils (Qualls and Haines, 1992). DOC production rates reported in this paper are minimum values. Under oxic conditions, and particularly for the plant tissue samples, a significant proportion of the DOC released by the samples was probably utilized microbially, either released as $\mathrm{CO}_{2}$ (leading to a double-counting of C) or incorporated into microbial tissue during the incubation.

Guggenberger et al. (1994) examined the origin of DOC and its pathways of mobilization in spruce forest floors and concluded that the complex mixture of DOC represents a combination of plant-derived and microbial metabolite products. They proposed that the hydrophobic and hydrophilic acid and neutral fractions contained different compounds relating to their plant or microbial origin. DOC can be released through the leaching of organic matter and plant tissues or the product of microbial degradation of soil organic matter. In spruce forest floors, Christ and David (1996b) recognized entrained and adsorbed DOC phases, which were released by leaching and replenished by production (dominantly hydrophobic fractions) and microbial activities (dominantly hydrophilic fractions). They noted that the build-up of high DOC concentrations could inhibit the release of DOC, particularly the hydrophobic fractions. Qualls and Haines (1992) also ascribed much of the variation in DOC concentrations in soils to processes of adsorption.

There was little evidence in the present study for the inhibition of DOC release through the buildup of large DOC concentrations in porewater; this may be because the incubations were conducted for only 20 days, after which the water was replaced. Christ and David (1996b) observed much greater rates of DOC production in spruce forest floors when the leaching was frequent (once per day compared with once per week). The differences in DOC production among the three phases of the experiment suggest that the mechanisms of DOC production, microbial solubilization and leaching, vary among the substrate types and experimental conditions. Clearly important in controlling DOC production is the type of substrate, especially its chemical composition and degree of decomposition, with smaller amounts of DOC released from better decomposed materials. Working with eight red spruce forest floors, Gödde et al. (1996) observed a positive correlation between the amount of DOC released and the $\mathrm{C}: \mathrm{N}$ ratio of the sample, which may relate to degree of decomposition.

The production of DOC showed a more limited response to increasing temperature than $\mathrm{CO}_{2}$ production. In this study, the $\mathrm{Q}_{10}$ value for $\mathrm{DOC}$ production over the range 4 to $22{ }^{\circ} \mathrm{C}$ averaged 1.6. In studies of DOC release from forest floors, Christ and David (1996a) and Gödde et al. (1996) reported $\mathrm{Q}_{10}$ values ranging from 1.5 to 2.0. These temperature responses of DOC production are smaller than is commonly observed for $\mathrm{CO}_{2}$ release from soils. Emission of $\mathrm{CO}_{2}$ was not measured at $4{ }^{\circ} \mathrm{C}$ in the present study, but Gödde et al. (1996) observed $\mathrm{Q}_{10}$ values for $\mathrm{CO}_{2}$ emission from forest floors of 2.6 to 3.3 , over the temperature range of 3 to $20^{\circ} \mathrm{C}$, and Kirschbaum 
(1995) noted that $\mathrm{Q}_{10}$ values decrease as temperature increases, from about 4.5 at $10{ }^{\circ} \mathrm{C}$ to 2.5 at $20^{\circ} \mathrm{C}$. Boone et al. (1998) recently presented data that suggested the $Q_{10}$ values for soil respiration in profiles lacking roots was 2.5, whereas this value rose to 4.6 for root respiration and rhizosphere decomposition.

The weaker response of DOC release to temperature, compared with $\mathrm{CO}_{2}$ emission, may be related to the involvement of DOC production with both microbial enzymatic activity and physical leaching of the material, the latter being less sensitive to temperature change. The limited temperature response of DOC release from the fresh maple leaves, in which leaching is probably the dominant process of DOC release, supports this contention. Furthermore, the study determined net DOC production, a function of DOC release and microbial consumption, and the combination of these processes may reduce the overall sensitivity to temperature further. Although there was no variation in water content in the present study (all samples were saturated), Christ and David (1996a) and Gödde et al. (1996) showed that both increasing soil moisture content and more frequent leaching increased the rate of DOC production. Thus, warmer and wetter environments increase rates of DOC production.

The observation that DOC production was similar under oxic and anoxic conditions was unexpected. If much of the release of DOC is related to microbial activity, then one would have anticipated lower DOC production rates under anoxic conditions, as was clearly observed for $\mathrm{CO}_{2}$ production. Under oxic conditions, however, some of the DOC produced may have been consumed by microbes, lowering the observed net DOC production rate, which may, in part, have caused this condition. DOC lability would be much smaller under anoxic conditions compared with oxic conditions. The cool, wet, anoxic conditions found in peatlands may thus be the ideal conditions for DOC production and may account for the high DOC concentrations found commonly in peat porewaters.

Caution should be exercised, however, in translating the absolute DOC production rates observed in this laboratory incubation to field conditions. For example, peat profiles contain about $100 \mathrm{~kg}$ organic matter $\mathrm{m}^{-2}$ in the top meter of the profile. Assuming that much of the profile is cool and anoxic, the results of this study suggest that the peat would produce between 1 and $2 \mathrm{mg}$ DOC $\mathrm{g}^{-1}$ over 60 days. This translates into total DOC production in the profile of be- tween 200 and $400 \mathrm{~g} \mathrm{~m}^{-2}$ over a 120-day season. DOC export from catchments dominated by peatlands rarely exceeds $50 \mathrm{~g} \mathrm{~m}^{-2} \mathrm{yr}^{-1}$ (Moore, 1997). Clearly, there must be less DOC produced under field conditions, or processes affecting DOC production such as inhibition, adsorption, or microbial utilization reduce the net production rate to the observed export rate of peatlands.

The results of this study suggest that there may be a general relationship in the partitioning of $\mathrm{C}$ mobilized as DOC and $\mathrm{CO}_{2}$ under oxic and anoxic conditions (Fig. 4). The higher the DOC production rate under oxic conditions, the smaller the ratio of $\mathrm{CO}_{2}$ to DOC production. The eight red spruce forest floors incubated by Gödde et al. (1996) also follow this pattern, when corrected to $20{ }^{\circ} \mathrm{C}$, falling between the values of DOC and $\mathrm{CO}_{2}$ production observed in the fresh and old maple leaves. In their model of DOC leaching from forest floors, compared with field measurements, Currie and Aber (1997) ascribed the highest proportion of C loss as DOC (compared with $\mathrm{CO}_{2}$ ) to the least decomposed materials (e.g. lignocellulose and unprotected cellulose fractions), and confirmed the importance of substrate chemistry and degree of decomposition on $\mathrm{CO}_{2}$ and

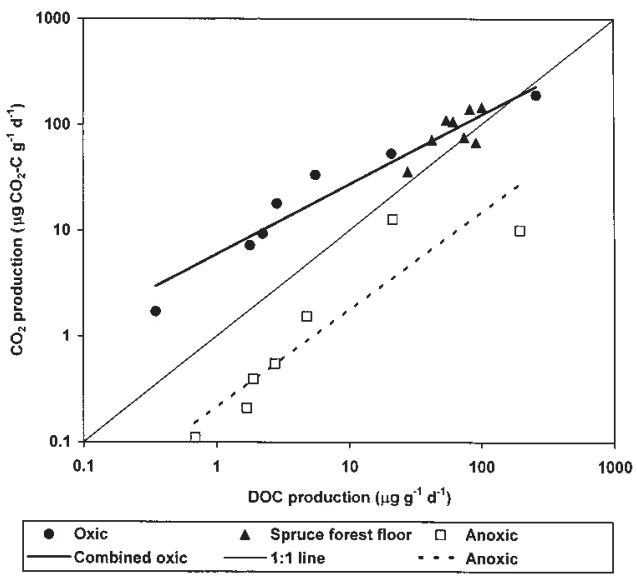

Fig. 4. The partitioning of mobilized $\mathrm{C}$ between $\mathrm{DOC}$ and $\mathrm{CO}_{2}$ during the oxic and anoxic incubations at $22{ }^{\circ} \mathrm{C}$ reported here, and oxic incubations of eight red spruce forest floors at $10{ }^{\circ} \mathrm{C}$, corrected to $20^{\circ} \mathrm{C}$, reported by Gödde et al. (1996). The upper line represents the regression between $\mathrm{CO}_{2}$ and DOC production for the 15 oxic incubations: $\log _{10} \mathrm{CO}_{2}=0.576( \pm 0.121)+$ $0.758( \pm 0.079) \log _{10} \mathrm{DOC}, r^{2}=0.875$. The middle line represents the 1:1 relationship. The lower line represents the regression for the seven anoxic incubations: $\log _{10} \mathrm{CO}_{2}=-0.647( \pm 0.183)+0.890( \pm 0.173) \log _{10}$ DOC, $r^{2}=0.841$. 
DOC production rates. These relationships of DOC and $\mathrm{CO}_{2}$ production from decomposing soil materials deserve further investigation.

\section{ACKNOWLEDGMENTS}

This work was funded by the Natural Sciences and Engineering Research Council of Canada.

\section{REFERENCES}

Andersson, S., S. I. Nilsson, and P. Saetre. 2000. Leaching of dissolved organic carbon (DOC) and dissolved organic nitrogen (DON) in mor humus as affected by temperature and $\mathrm{pH}$. Soil Biol. Biochem. 32:1-10.

Boone, R. D., K. J. Nadelhoffer, J. D. Canary, and J. P. Kaye. 1998. Roots exert a strong influence on the temperature sensitivity of soil respiration. Nature 396:570-572.

Boyer, J. N., and P. M. Groffman. 1996. Bioavailability of water extractable organic carbon fractions in forest and agricultural soil profiles. Soil Biol. Biochem. 28:783-790.

Christ, M., and M. B. David. 1996a. Temperature and moisture effects on the production of dissolved organic carbon in a Spodosol. Soil Biol. Biochem. 28:1191-1199.

Christ, M., and M. B. David. 1996b. Dynamics of extractable organic carbon in Spodosol forest floors. Soil Biol. Biochem. 28:1171-1179.

Cronan, C. S., and G. R. Aiken. 1985. Chemistry and transport of soluble humic substances in forested watersheds of the Adirondack Park, New York. Geochim. Cosmochim. Acta 49:1697-1705.

Currie, W. S., and J. D. Aber. 1997. Modeling leaching as a decomposition process in humid montane forests. Ecology 78:1844-1860.

Dalva, M., and T. R. Moore. 1991. Sources and sinks of dissolved organic carbon in a forested swamp catchment. Biogeochemistry 15:1-19.

DeLuca, T. H., and D. R. Keeney. 1993. Soluble anthrone-reactive carbon in soils: Effect of carbon and nitrogen amendments. Soil Sci. Soc. Am. J. 57: 1296-1300.

Dosskey, M. G., and P. M. Bertsch. 1994. Forest sources and pathways of organic matter transport to a blackwater stream: A hydrologic approach. Biogeochemistry 24:1-19.

Gödde, M., M. B. David, M. Christ, M. Kaupenjohann, and G. F. Vance. 1996. Carbon mobilization from the forest floor under red spruce in the northeastern U.S.A. Soil Biol. Biochem. 28:1181-1189.

Guggenberger, G., W. Zech, and H.-F. Schulten. 1994. Formation and mobilization pathways of dissolved organic matter: evidence from chemical structure studies or organic matter fractions in acid forest floor solutions. Org. Geochem. 21:51-66.

Kaiser, K., G. Guggenberger, and W. Zech. 1996. Sorp- tion of DOM and DOM fractions to forest soils. Geoderma 74:281-303.

Kaiser, K., and W. Zech. 1998. Rates of dissolved organic matter release and sorption in forest soils. Soil Sci. 163:714-725.

Kirschbaum, M. U. E. 1995. The temperature dependence of soil organic matter decomposition and the effect of global warming on soil organic C storage. Soil Biol. Biochem. 27:753-760.

Koprivnjak, J-F., and T. R. Moore. 1992. Sources, sinks and fluxes of dissolved organic carbon in subarctic fen catchments. Arct. Alp. Res. 24:204-210.

Leff, L. G., and J. L. Meyer. 1991. Biological availability of dissolved organic carbon along the Ogeechee River. Limnol. Oceanogr. 36:315-323.

Marin, L. E., T. K. Kratz, and C. J. Bowser. 1990. Spatial and temporal patterns in the hydrogeochemistry of a poor fen in northern Wisconsin. Biogeochemistry 11:63-76.

McDowell, W. H., and T. Wood. 1984. Podzolization: Soil processes control dissolved organic carbon concentrations in stream water. Soil Sci. 137:13-32.

Moore, T. R. 1989. Concentrations, fluxes and characteristics of dissolved organic carbon in forested and disturbed catchments, Westland, New Zealand. I. Maimai. Water Resour. Res. 25:1321-1330.

Moore, T. R. 1997. Dissolved organic carbon: Sources, sinks and fluxes and role in the soil carbon cycle. In Soil Processes and the Carbon Cycle. R. Lal, J.M. Kimble, R.F. Follett, and B.A. Stewart (eds.). CRC Press, Boca Raton, FL, pp. 281-292.

Moore, T. R., and R. J. Jackson. 1989. Concentrations, fluxes and characteristics of dissolved organic carbon in forested and disturbed catchments, Westland, New Zealand. II. Larry River. Water Resour. Res. 25:1331-1339.

Moore, T. R., W. de Souza, and J-F. Koprivnjak. 1992. Controls on the sorption of dissolved organic carbon by soils. Soil Sci. 154:120-129.

Qualls, R. G., and B. L. Haines. 1991. Geochemistry of dissolved organic nutrients in water percolating through a forest ecosystem. Soil Sci. Soc. Am. J. 55:1112-1123.

Qualls, R. G., and B. L. Haines. 1992. Biodegradability of dissolved organic matter in forest throughfall, soil solution, and stream water. Soil Sci. Soc. Am. J. 56:578-586.

Søndergaard, M., and M. Middelboe. 1995. A cross-system analysis of labile dissolved organic carbon. Mar. Ecol. Prog. Ser. 118:283-294.

Thurman, E. M. 1985. Organic Geochemistry of Natural Waters. M. Nijhoff/W. Junk Publishers, Boston.

Yano, Y., W. H. McDowell, and N. E. Kinner. 1998. Quantification of biodegradable dissolved organic carbon in soil solution with flow-through bioreactors. Soil Sci. Soc. Am. J. 62: 1556-1564. 